\title{
Mature Ovarian Teratoma
}

\author{
K. Tzvetankov ${ }^{1}$, G. Hadjidekov ${ }^{1}$, I. Plachkov ${ }^{2}$, M. Hristova-Turlakova ${ }^{3}$ \\ ${ }^{1,2}$ Department of Radiology, University Hospital “Lozenets” Sofia, Bulgaria \\ ${ }^{3}$ Department of Obstetrics and Gynaecology, University Hospital “Lozenets” Sofia, Bulgaria
}

\begin{abstract}
Teratomas are the most common ovarian germ cell tumors, presenting a variety of histological aspects. They are often multicystic and contain sebaceous fluid, skin, hair and teeth. Most of them are asymptomatic and rarely manifest with abdominal pain. Imaging plays the main role in the diagnosis with ultrasonography (US) as the first and magnetic renonance imaging (MRI) as the preferred method of choice as a valuable adjunct for further characterization of these lesions. Our case demonstrate the supplementary role of MRI of a mature cystic teratoma origination from the left ovary.
\end{abstract}

Keywords: teratomas, germ cell tumor, sonography, MRI

\section{Background}

Teratomas are a variety of histological variants, all of which contain mature or immature tissues from germ cell origin. The most common variant is the mature cystic teratoma which is made up of ecto-, endo- and mesodermal tissues. Magnetic resonance imaging is the method of choice used to characterize these lesions after initial ultrasound diagnostics, because of its bigger field of view and better resolution.

\section{Case}

On a routine gynecological checkup a tumor formation arising from the pelvis was diagnosed via ultrasound. The tumor expresses mass effect on the uterus and reaches the level of the umbilicus.

The patient was sent to our radiology department for further evaluation with MRI and surgical planning.

At ultrasound a homogenous hyperechoic mass with fine contours and margins is visualized (fig.1a). There is a nodule demonstrating itself with an "egg shell" sign with distal acoustic shadowing in the base of the tumor (fig.1b). The uterus is of normal size and shape (fig.1c). In the right ovary there are a few follicular cysts which are normal findings correlating with the menstrual cycle (fig.1d).

On MRI the formation was seen to originate from the left ovary. The tumor is of high signal intensity on T1 and T2 (fig. 2a,b,c,d). On T1 and T2 FAT SAT sequences the high intensity regions were suppressed (fig.3 a,b,c). The Rockitansky nodule is seen as a round lesion included in the mass with absence of signal intensity on all sequences, representing solid components of hair, skin and probably teeth. The uterus is shifted dorsally and the bladder is compromised from the above. There are no signs of invasion to the surrounding structures. The right ovary is with an appearance with full correlation with the ultrasound image. (fig.3b).

Cystectomy was performed as the next level of treatment and diagnosis.
In-situ, the uterus was of normal size, form and mobility and shifted dorsally from a $25 \mathrm{~cm}$ in size cystic formation arising from the left ovary (fig 5). The formation was well demarcated and with dense consistency. The fallopian tubes and the right ovary were with no pathological changes.

The histological report is of a mature cystic teratoma.

\section{Discussion}

Mature cystic teratomas are made up of different types of well differentiated derivates of at least two germanative cell types. They are 4 to $5 \mathrm{~cm}$ in size, but can become as large as $45 \mathrm{~cm}$ in diameter. They develop most often in the $3 \mathrm{rd}$ and 4th decade of life $(5,7)$. Dermoid cysts are the mostcommon ovarian germ-cell tumor and most frequent abdominal mass in infants $(2,7,9,17)$. They originate from one germinative cell after the first mitotic division (10). Most teratomas are asymptomatic. Abdominal pain or other subjective complaints are rare (5).

Dermoids have a characteristic appearance. They are uniloculated in $88 \%$ of cases. The wall of the cyst is made up of squamous epithelium and is filled with sebaceous materials which are liquid to body and semi-solid to room temperature (4). Hair follicles, oil glands, muscles and other tissues lie upon or make up the wall of the cyst. A characteristic appearance is the presence of a knob in the tumor known as the "Rokintansky nodule" in which hair is included. When there are teeth or/and bones present, they are part of this nodule (11).

Ectodermal tissues are invariably present in these formations; mesodermal tissues are present in $90 \%$, while teeth and other components are present in $31 \%$ of cases $(\mathbf{1}, \mathbf{4}, \mathbf{7}$, 11).

The majority of teratomas are diagnosed with ultrasound, but sometimes the diagnosis may be hard to make, because these lesions in rare cases can have a non-characteristic appearance.

Teratomas are visualized as hypo or anechoic cystic masses with a hyperechoic Rokitansky nodule inside the lesion with distal acoustic shadowing (7). They can also be seen as par- 


\section{International Journal of Science and Research (IJSR) \\ ISSN (Online): 2319-7064 \\ Index Copernicus Value (2013): 6.14 | Impact Factor (2014): 5.611}

tially or diffusely hyperechoic masses containing sebaceous material $(\mathbf{6 , 1 3})$. The third type of manifestation presents with discrete hyperechoic drags representing hair inside the tumor (16). In some casesliquid-liquid levels may be seen which are a result of sebum lying above pure liquid substances and is more hyperechoic than water (6). The nodule is hyperehoic with distal acustic loss, because of solid compartments making up the lump.

On CT the diagnosis is straight forward, because of the bigger field of view favoring a much better spatial orientation and the ability to measure density of different tumor structures. The fat is measured as negative Hounsfield units and positive for the solid compartments. $(\mathbf{3 , 1 2})$ (fig $\mathbf{4 a , b , c ) . ~}$

On MRI, sebum demonstrates a high $\mathrm{T} 1$ and $\mathrm{T} 2$ intensity close to that of retroperitoneal fat which on sequences like T2 and T1 with fat suppression are of low signal intensity. Hemorrhage needs to be excluded with GE and T2* sequences which are sensitive to breakdown products of hemoglobin in cases when chocolate cysts in endometriosis are suspected $(7,8,14,15,17,18)$. A very small percent of dermoid cysts do not contain sebaceous materials, but in these cases they contain fat in the cyst wall or the Rokintansky nodule (7). These tumors hide a risk of several complications which are all extremely rare, but do exist. The most common complication is rupture of the cyst and subsequent development of granulomatous peritonitis (5) or isolated infection of the cyst may also be a case. Malignant degeneration from the cells covering the cyst wall into carcinoma or sarcoma (15) or torsion of the ovary from the mass effect of the tumor are very rare complications (5).

\section{Conclusion}

Mature cystic teratomas via all imaging modalities are seen as masses containing fat which is of sebaceous material inside the cavity, the wall of the cyst and inside the Rokitansky nodule. CT and MRI are methods which are dominant to all other non-invasive diagnostic methods because of their bigger field of view, hence excellent spatial orientation and better depiction of the tissues making up the tumor which is the key to the diagnosis.
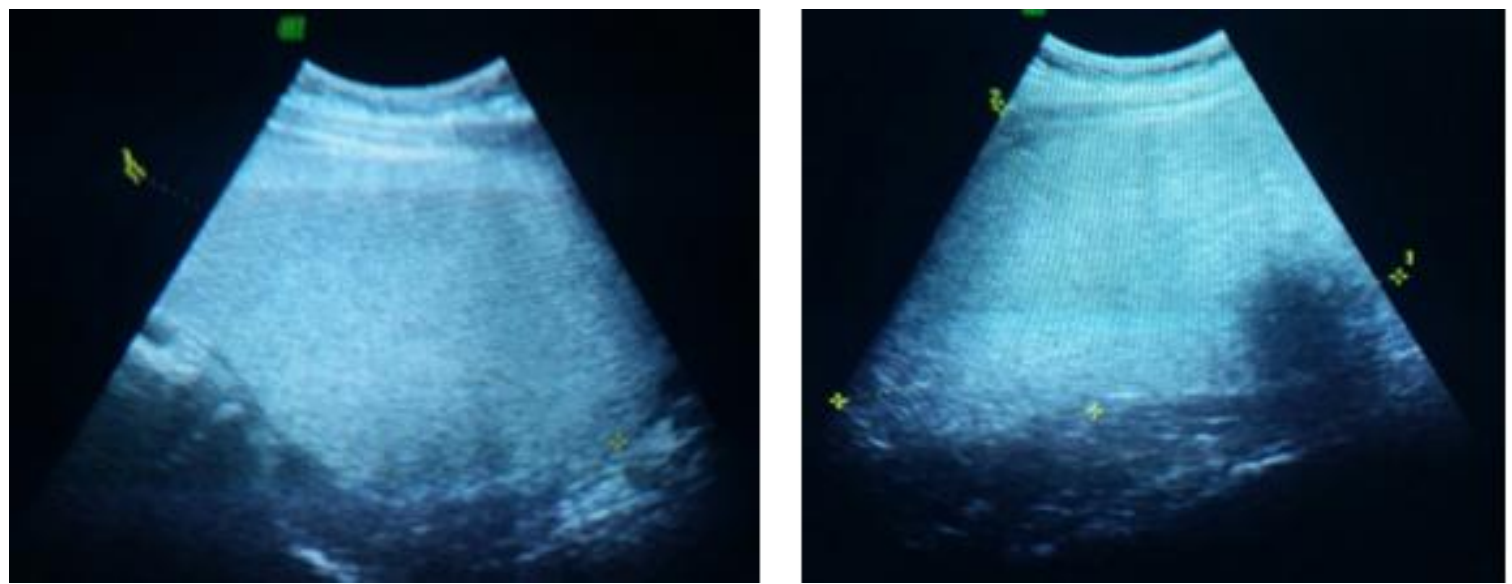

Figure 1a and b: a hyperechoic mass with fine margins and contours with an "egg shell" embodiment in the base of the mass with distal acoustic shadowing, corresponding with the Rokintansky nodule.

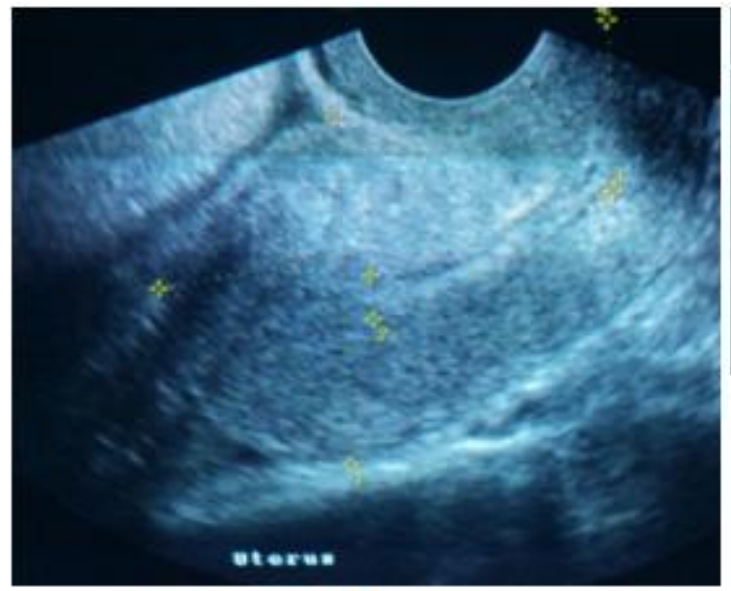

c)

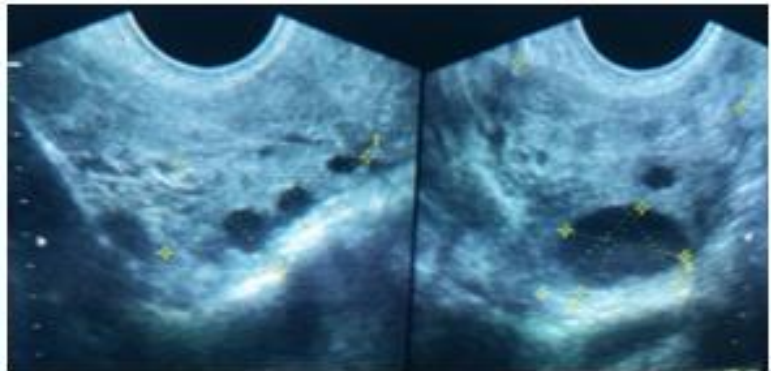

d)

Figure 1: $\mathrm{c}$ and d demonstrate the normal uterus and the right ovary with follicular cysts. 


\section{International Journal of Science and Research (IJSR) \\ ISSN (Online): 2319-7064}

Index Copernicus Value (2013): 6.14 | Impact Factor (2014): 5.611

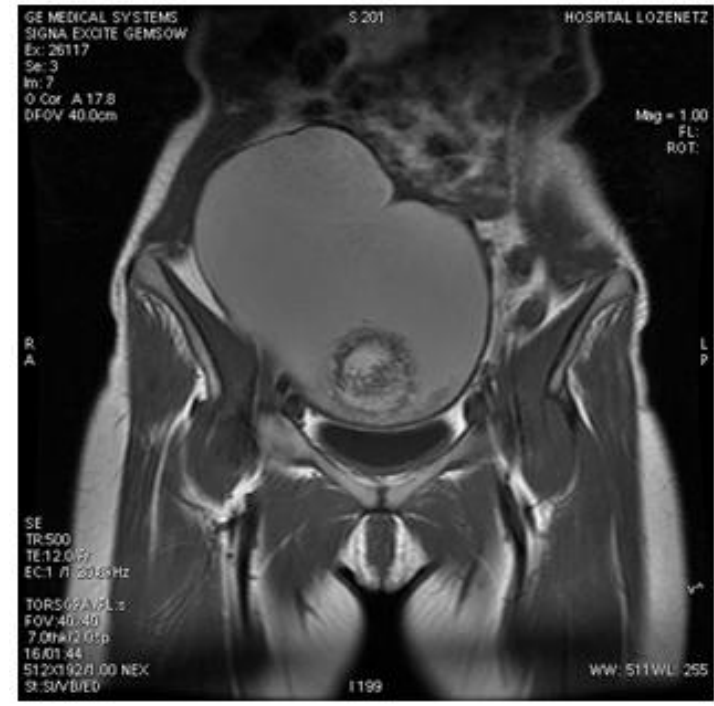

(a)

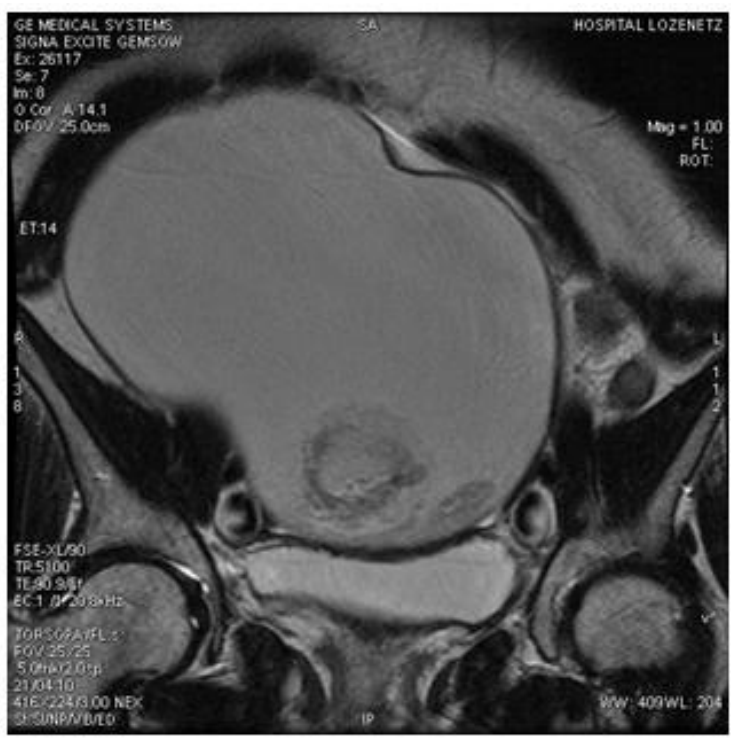

b)

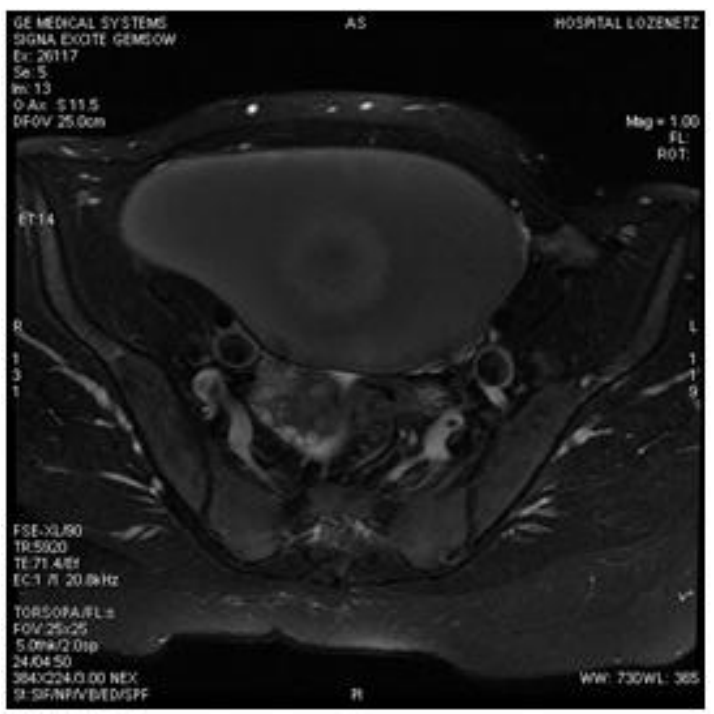

a)

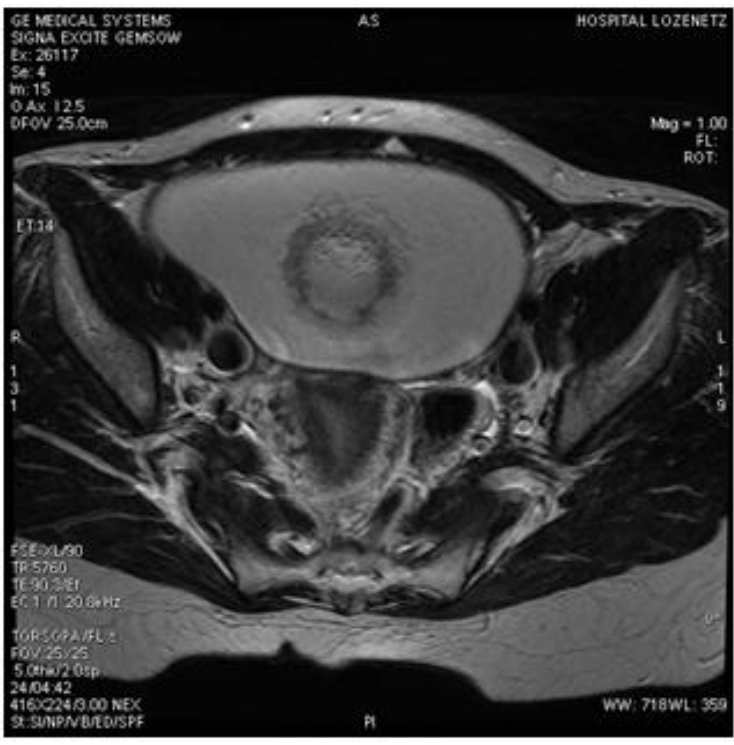

c)

Figure 2: a COR T1, 2b COR T2, 2c AX T2, 2d SAG T2 a high intensity on $\mathrm{T} 1$ and $\mathrm{T} 2$ formation arising from the left ovary and causing mass effect on the uterus and bladder.

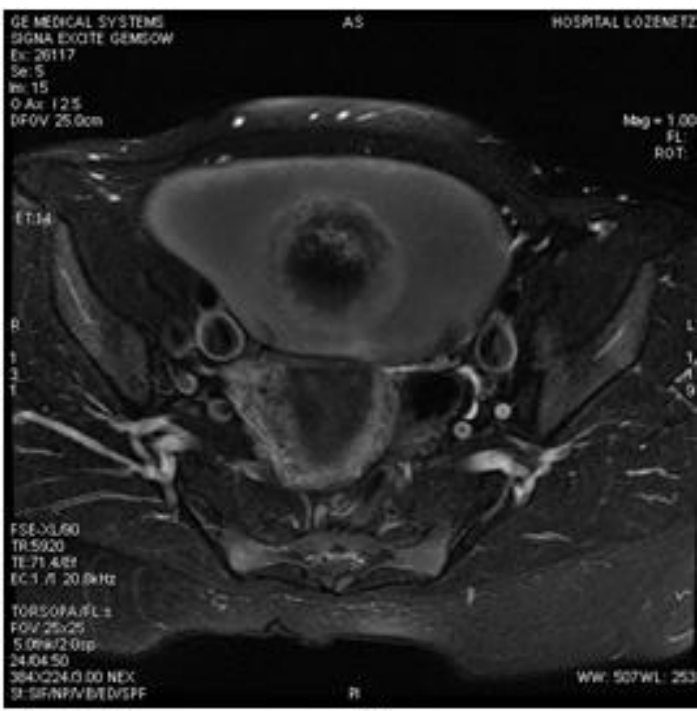

b)

Figure 3: a,b - AX T2 FAT SAT, here the right ovary is easily evaluated with an appearance correlating to the one seen on ultrasound.

Volume 5 Issue 1, January 2016 www.ijsr.net 


\section{International Journal of Science and Research (IJSR) \\ ISSN (Online): 2319-7064}

Index Copernicus Value (2013): 6.14 | Impact Factor (2014): 5.611

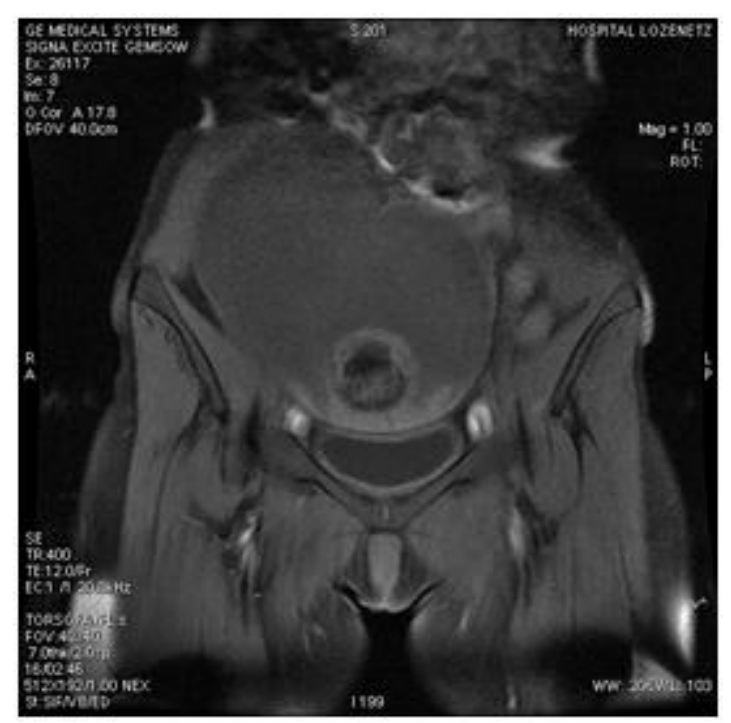

(c)

Figure 3: c - COR T1 FAT SAT, the mass is suppressed on $\mathrm{T} 1$ and $\mathrm{T} 2$ with fat saturation with the Rokitansky nodule lying in the base of the tumour which is with lack of signal intensity, because of its solid nature.

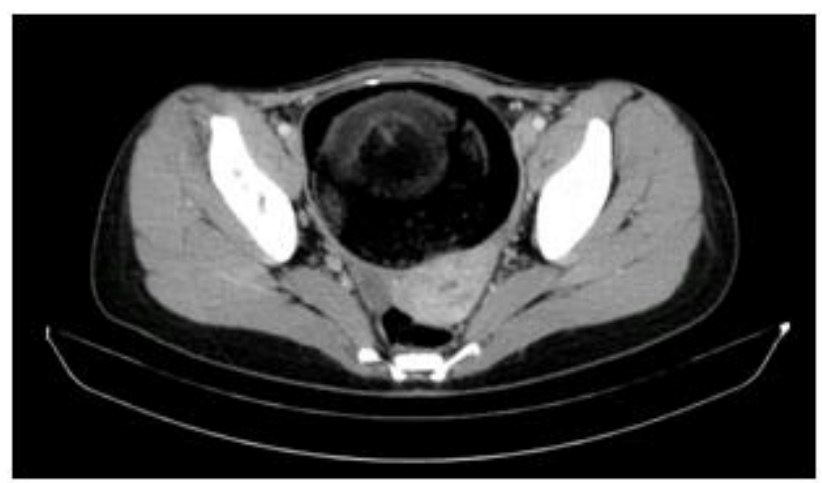

On Fig. 4a is a non-contrast CT of another patient used as a demonstration for the appearance of a similar looking teratoma of the left ovary. A mass arising from the left ovary is seen with fine margins and contours. The formation is made up of dominating low density regions correlating with fat. There are soft tissue inclusions in the mass which represent tissues from ecto- and mesodermal origin.

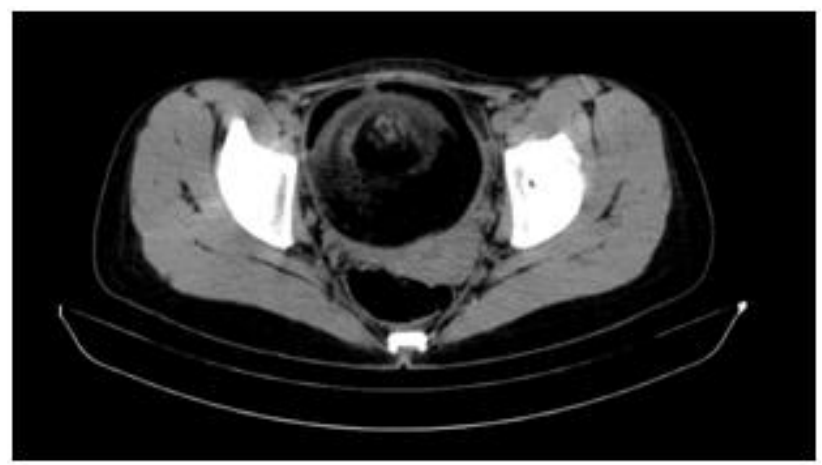

On Fig. 4b arterial phase CT

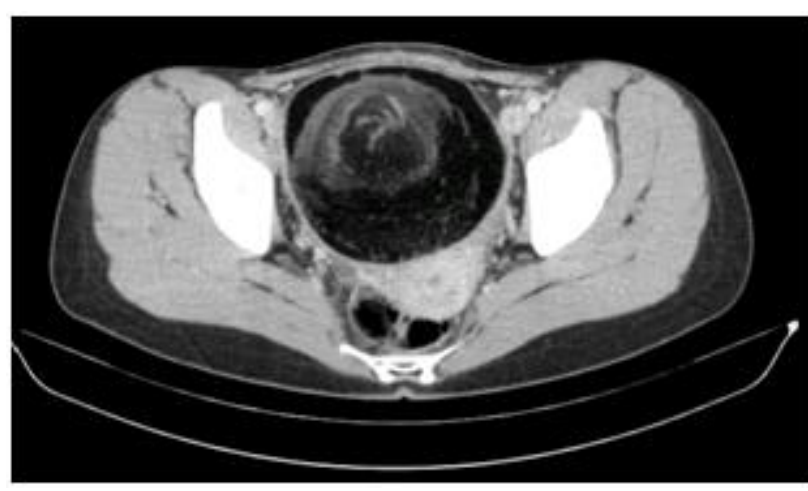

Fig. 4c venous phase CT we can appreciate uptake of contrast material on the venous phase it the soft tissue compartments and the cyst wall.

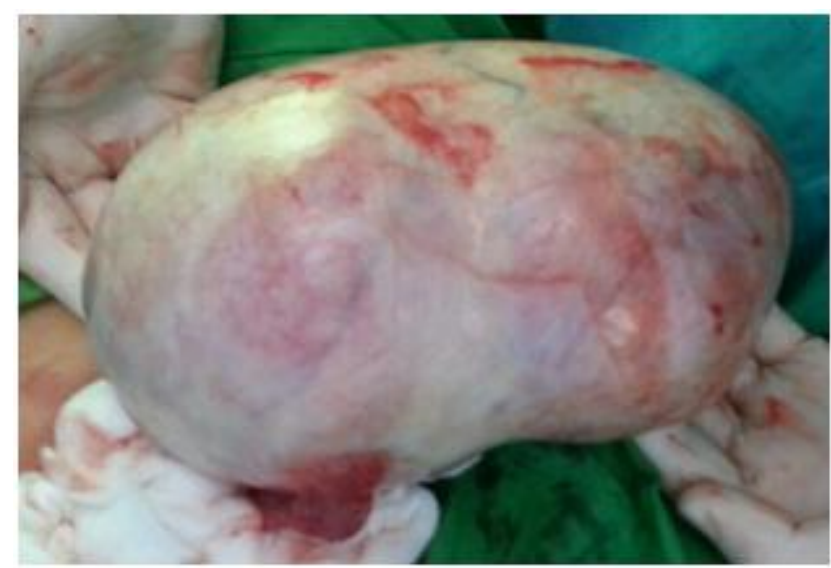

Fig 5.of the postoperative macroscopic appearance of the mature dermoid cyst diagnosed via ultrasound and MRI

\section{References}

[1] Blackwell WJ, Dockerty MB, Mason JC, Mussey RD. Dermoid cysts of the ovary: their clinical and pathological significance. Am J Obstet Gynecol 1946; 51:151172. Medline

[2] Brown MF, Hebra A, McGeehin K, Ross AJ, III. Ovarian masses in children: a review of 91 cases of malignant and benign masses. J Pediatr Surg 1993; 28:930933. CrossRef, Medline

[3] Buy JN, Ghossain MA, Moss AA, et al. Cystic teratoma of the ovary: CT detection. Radiology 1989; 171:697701. Abstract, Medline

[4] Caruso PA, Marsh MR, Minkowitz S, Karten G. An intense clinicopathologic study of 305 teratomas of the ovary. Cancer 1971; 27:343-348. CrossRef, Medline

[5] Comerci JT, Jr, Licciardi F, Bergh PA, Gregori C, Breen JL. Mature cystic teratoma: a clinicopathologic evaluation of 517 cases and review of the literature. Obstet Gynecol 1994; 84:22-28. Medline

[6] Dodd GD, Budzik RF. Lipomatous tumors of the pelvis in women: spectrum of imaging findings. AJR Am J Roentgenol 1990; 155:317-322. CrossRef, Medline

[7] Eric K. Outwater, MD, Evan S. Siegelman, MD, and Jennifer L. Hunt, MD Ovarian Teratomas: Tumor Types and Imaging Characteristics RSNA Radiographic March 2001 volume 21 , Issue 2

[8] Guinet C, Buy JN, Ghossain MA, et al. Fat suppression techniques in MR imaging of mature ovarian teratomas: 
comparison with CT. Eur J Radiol 1993; 17:117-121. CrossRef, Medline

[9] Koonings PP, Campbell K, Mishell DR, Jr, Grimes DA. Relative frequency of primary ovarian neoplasms: a 10year review. Obstet Gynecol 1989; 74:921-926. Medline

[10] Linder D, McCaw BK, Hecht F. Parthenogenic origin of benign ovarian teratomas. N Engl J Med 1975; 292:6366. CrossRef, Medline

[11] Matz MH. Benign cystic teratomas of the ovary. Obstet Gynecol Surv 1961; 16:591-605. CrossRef, Medline

[12] Occhipinti KA, Frankel SD, Hricak H. The ovary: computed tomography and magnetic resonance imaging. Radiol Clin North Am 1993; 31:1115-1132. Medline

[13] Patel MD, Feldstein VA, Lipson SD, Chen DC, Filly RA. Cystic teratomas of the ovary: diagnostic value of sonography. AJR Am J Roentgenol 1998; 171:10611065. CrossRef, Medline

[14] Scoutt L, McCarthy S, Lange R, Bourque A, Schwartz P. MR evaluation of clinically suspected adnexal masses. J Comput Assist Tomogr 1994; 18:609-618. CrossRef, Medline

[15] Sheth S, Fishman EK, Buck JL, Hamper UM, Sanders RC. The variable sonographic appearances of ovarian teratomas: correlation with CT. AJR Am J Roentgenol 1988; 151:331-334. CrossRef, Medline

[16] Togashi K, Nishimura K, Itoh K, et al. Ovarian cystic teratomas: MR imaging. Radiology 1987; 162:669-673. $\underline{\text { Abstract, }} \underline{\text { Medline }}$

[17] Whitecar MP, Turner S, Higby MK. Adnexal masses in pregnancy: a review of 130 cases undergoing surgical management. Am J Obstet Gynecol 1999; 181:19-24. CrossRef, Medline

[18] Yamashita Y, Torashima M, Hatanaka Y, et al. Value of phase-shift gradient-echo MR imaging in the differentiation of pelvic lesions with high signal intensity at T1weighted imaging. Radiology 1994; 191:759-764. $\underline{\text { Abstract, }}$ Medline 